\title{
Livestock-associated methicillin-resistant Staphylococcus aureus (LA-MRSA) prevalence in humans in close contact with animals and measures to reduce on-farm colonisation
}

\author{
Daniel Crespo-Piazuelo and Peadar G. Lawlor
}

\begin{abstract}
Since the 1940s, Staphylococcus aureus has adapted to the use of different antimicrobials to treat infections. Although S. aureus can act as a commensal bacterium, some strains are facultative pathogens and acquiring them can be fatal. In particular, treating infections caused by $S$. aureus with acquired antimicrobial resistance is problematic, as their treatment is more difficult. Some of these $S$. aureus variants are methicillin-resistant $S$. aureus (MRSA) with prevalence across the globe in health-care facilities, community settings and on livestock farms. Apart from humans, MRSA can colonise other animal species, and because of this, resistance to new antimicrobials can appear and jump between species. Livestock and companion animals are particularly important in this regard considering the relatively high usage of antimicrobials in these species. There is a risk to humans who come into direct contact with animals acquiring MRSA but there is also the risk of animals acquiring MRSA from colonised humans. In this review, we summarise studies conducted worldwide to characterise the prevalence of MRSA in veterinarians, farmers and other personnel who come into close contact with animals. Finally, alternative treatment, preventive measures and on-farm strategies to reduce MRSA introduction to a farm and carriage within a herd are discussed.
\end{abstract}

Keywords: LA-MRSA, Animal production, Prevention, Antimicrobial resistance, Animal contact

\section{Introduction}

Staphylococcus aureus is a Gram-positive catalase-positive bacterium which is commonly found on the skin and mucosa of humans and animals [1-3]. The anterior nares of humans are one of the most frequently colonised sites and about $30 \%$ of the human population is colonised with $S$. aureus $[3,4]$. Although $S$. aureus is usually classified as a commensal bacterium, it is a facultative pathogen, which can potentially cause several diseases from mild skin lesions to severe and potentially fatal infections [5]. As a commensal bacterium, $S$. aureus colonises its host

*Correspondence: Peadar.Lawlor@teagasc.ie

Teagasc, Pig Development Department, Animal \& Grassland Research \& Innovation Centre, Moorepark, Fermoy, Co. Cork P61 C996, Ireland without impacting the health of the host. Depending on the persistence of carriage, hosts can be persistent carriers, intermittent carriers, or non-carriers at all, if the bacterium rarely colonises the host, and when it does, the colonisation is transient and does no last longer than about two weeks [6]. However, nasal swabs from persistent carriers usually yield the same MRSA strains over time, and because of the facultative pathogenicity of $S$. aureus, persistent carriers are at a higher risk of developing an infection [6].

Within a few years of the introduction of penicillin in the 1940s, the first cases of penicillin-resistant S. aureus were reported [7]. Resistance was obtained through the acquisition of plasmids that contained the ß-lactamase gene (blaZ), which produce an enzyme capable of original author(s) and the source, provide a link to the Creative Commons licence, and indicate if changes were made. The images or other third party material in this article are included in the article's Creative Commons licence, unless indicated otherwise in a credit line to the material. If material is not included in the article's Creative Commons licence and your intended use is not permitted by statutory regulation or exceeds the permitted use, you will need to obtain permission directly from the copyright holder. To view a copy of this licence, visit http://creativecommons.org/licenses/by/4.0/. The Creative Commons Public Domain Dedication waiver (http://creativeco mmons.org/publicdomain/zero/1.0/) applies to the data made available in this article, unless otherwise stated in a credit line to the data. 
breaking down the $\beta$-lactam ring of penicillin and other antibiotics [8-10]. The $\beta$-lactam ring of penicillin causes bacterial lysis by binding to penicillin-binding proteins (PBP), which are needed for cross-linking the peptidoglycan chains of the cell wall [11].

Methicillin, a new antibiotic with resistance to $\beta$-lactamase was developed two decades later, in 1960, and in less than two years, the first methicillin-resistant S. aureus (MRSA) appeared [12, 13]. This new resistance was driven by the acquisition of the $m e c A$ gene, which encodes the penicillin-binding protein $2 \mathrm{a}$ (PBP2a), a slightly different PBP that possesses low affinity for $\beta$-lactam antibiotics [14].

Later on, in the 1980s and 1990s, MRSA strains spread across the world carrying multidrug resistant traits and being one of the most important agents of nosocomial infection [5]. These MRSA strains were called hospitalacquired MRSA (HA-MRSA), as they were commonly found in hospitals and health care facilities.

In parallel with the spread of HA-MRSA, control measures were applied in hospital settings to prevent nosocomial transmission of MRSA [15]. These preventive measures reduced HA-MRSA prevalence in several countries. However, infections caused by new MRSA strains started to increase in communities outside the hospital setting in the 1990s $[16,17]$. These strains which could spread rapidly among groups of healthy individuals were called community-acquired MRSA (CA-MRSA) [18].

In 2004, a new MRSA strain was found colonising the daughter of a pig farmer in the Netherlands [19]. Both parents and a pig on the family farm carried the same strain, which was characterized by the presence of the $m e c A$ gene. This strain was different from those usually found in HA-MRSA and CA-MRSA, as it was impossible to classify it using the standard method of pulsed-field gel electrophoresis (PFGE) with restriction endonuclease SmaI. Although other studies previously reported a linkage between animal and human MRSA colonisation, this was the first study to demonstrate the transmission of MRSA between animals and humans. Later on, several other studies reported this in other countries. The term livestock-associated MRSA (LA-MRSA) was used to refer to this third group of MRSA strains which were considered a reservoir in livestock animals [20].

There are several methods for screening and typing MRSA strains: spa sequence typing; multilocus sequence typing (MLST); staphylococcal cassette chromosome mec (SCCmec) typing; PFGE; and multilocus variable-number tandem repeat (VNTR) analysis (MLVA) (reviewed in [21, 22]). Based on MLST, strains are assigned to a sequence type (ST) after sequencing seven endogenous genes. Identical strains by MLST are assigned to the same $\mathrm{ST}$, while strains with closely related STs may belong to the same clonal complex (CC) lineage (e.g., CC398). Another most commonly used method is spa typing, based on sequencing the variable $\mathrm{X}$ region of the $S$. aureus surface protein A (spa) gene and assigning the strains to a spa type based on the different polymorphisms found (e.g., t011). The last method that has received most attention is SCCmec typing, which sequences and classifies the strains based on the differences in mobile genetic elements (MGE) including the aforementioned mecA gene (e.g., SCCmec IV). Despite the efforts in classifying the different MRSA strains found, the epidemiology of MRSA colonisation is changing. Strains of CA-MRSA can share genes between both LA- and HA- MRSA [23], and some clones are present in more than one classification group, blurring the distinction between strains [24-26].

LA-MRSA strains can be transmitted between different animal species and to humans who come in close contact with colonised animals, such as veterinarians and farm workers. However, colonised humans can also transmit LA-MRSA to other humans and between animal settings. In this review, we have summarised studies conducted worldwide to assess the prevalence of MRSA in personnel who come into close contact with animals. We also discuss preventive measures to avoid MRSA introduction onto a farm, alternative treatments and on-farm strategies to reduce or eradicate MRSA carriage within a herd.

\section{MRSA transmission between humans, animal production and companion animals}

MRSA can be transmitted from vertebrate animals to humans. Likewise, humans also act as a reservoir for the transmission of $S$. aureus to vertebrate animals. Infections that can be present in both humans and animals and transmitted in both directions, such as $S$. aureus infections, are defined as "amphixenoses" [27]. The first reported incident of MRSA colonisation in livestock happened in Belgium in the early 1970s, affecting the milk of cows with bovine mastitis [28]. Despite most of the isolates having been similar to common bovine strains, a human-to-animal transmission of a new MRSA strain acquired by the farmer seems more likely due to the observed antimicrobial characteristics. Since then, MRSA colonisation has been reported in dogs, cats, horses, cattle, pigs, rabbits and poultry [29-32]. It has even been described in wild birds such as magpies and vultures [33]. The first animal-to-human transmission of S. aureus was reported in dairy sheep [34]. Shortly after, the first case of MRSA transmission from animal to human, including humanto-human transmission of the same strain was reported [19]. Other interspecies transmission have been 
described in household pets, which can be colonised with the same strains as their owners [35]. Nonetheless, despite the potential of $S$. aureus to colonise domestic and livestock animals, the primary reservoirs of LAMRSA in affected countries are those animals in intensive systems (i.e., pigs, veal calves, and broilers) [36].

S. aureus is usually transmitted by direct contact with colonised skin or with a mechanical vector [37]. In livestock systems, the most important ways of introducing MRSA onto a farm are the movement of MRSA colonised animals from one farm to another, direct contact with colonised humans and through animal contact with contaminated transport vehicles [38-40]. Another indirect way of transmitting MRSA between species is through the environment. S. aureus has a half-life of 5 days in dust, but it can survive in it for weeks [41]. These small particles can be transported to other farms on vehicles, and farm-workers can expose their families to the bacterium by bringing home dust covered clothes. Dust can also be transported by the wind along with other substances; airborne staphylococci has been detected at $477 \mathrm{~m}$ from a commercial broiler barn, and up to $530 \mathrm{~m}$ in theory [42]. Indeed, airborne-transmission of MRSA in hospitals [43], and to personnel that work more than $20 \mathrm{~h}$ per week in farm barns [44] is also possible. Apart from direct contact with animals or humans in contact with them, MRSA can also be transmitted through food production systems. Animals can act as a reservoir for antimicrobial-resistant bacteria and their products, such as meat, milk and eggs, can be a means of transmission of these bacteria to the consumer $[45,46]$. However, the risk of acquiring MRSA through food appears to be low [36].

Despite certain S. aureus strains being closely adapted to a specific host, they can be transmitted to other species [47-49]. These colonisations outside their preferred hosts are usually transient and generally do not last long [50], although some can be transmitted and sustained among the new host species [47, 49]. Moreover, MRSA strains continuously evolve in the host, and can even be replaced by other strains [51]. There are several factors that can influence MRSA transmission between animals and humans. The intensity/duration of animal contact is one such; farmers working more hours in a calf stable were more often carriers than farmers working fewer hours $[50,52]$. In the absence of animal contact, LAMRSA carriage was often reduced or lost, although some persistent carriers were reported [50]. Furthermore, the number of MRSA-positive animals within the farm also increases the probability of MRSA being transmitted to the farmer [52]. Following this trend, people living in areas with a higher livestock density (pigs, cattle, and veal calves) or in proximity to areas where pig manure is applied to crop fields are also at a higher risk of being colonised by LA-MRSA [53, 54].

\section{LA-MRSA colonisation in humans in close contact with animals}

Most of the LA-MRSA strains that colonise humans will not necessarily cause an infection, and when they occur they are usually less severe than those caused by HA- and CA-MRSA [55]. In addition, LA-MRSA strains represent a small proportion (3.9\%) of the isolated MRSA in humans in the European Union, but their proportion was higher $(\geq 10 \%)$ in five countries (Belgium, Denmark, the Netherlands, Slovenia and Spain) [56]. However, every $S$. aureus strain has the potential to evolve into a life-threatening pathogen [57]. For instance, in 2014, four patients died from LA-MRSA bacteraemia in Denmark, raising the concern regarding LA-MRSA in the European Union [56]. Today, hospital anamnesis usually includes questions to target farm workers or personnel in close contact with animal production settings due to their increased risk of being colonised with MRSA.

Several studies have concluded that humans in close contact with animals have greater risk of being colonised by LA-MRSA than the rest of the population [58-62]. Although some studies have reported that veterinarians are more likely to be MRSA carriers than farmers [60, 62], meta-analyses of published data established that livestock workers are at a higher risk to be colonised with LA-MRSA, more so if they are pig farmers $[63,64]$. However, colonisation in veterinarians is a potential thread for MRSA spread among farms. To assess the prevalence of MRSA colonisation in veterinarians, an NCBI Database search for the terms "veterinarian", "prevalence" and "MRSA" was conducted. The resulting studies are summarized in Table 1 , while the spa types carried by the humans analysed are reported in Fig. 1.

Prevalence of MRSA carriage in the general human population has been reported to be in the range of 0.8 1.3\% [79]. When the data presented in Table 1 relating to veterinary personnel is considered, the prevalence reported ranged between 0 and 50\% with an overall mean prevalence of $8 \%$ across studies, as most studies described a prevalence less than $10 \%$. Most of the studies considered in this review were conducted in Europe and the most commonly reported strain was CC398 (usually spa type t011), considered the dominant LA-MRSA strain in Europe. Some other strains such as CC5 (usually spa type t002) were reported as more dominant in Asia. HA-MRSA and CA-MRSA strains were also reported in these studies, making it difficult to discern the host preference of MRSA strains. Despite CC398 being considered the classical LA-MRSA strain, it originated in humans as methicillin-susceptible $S$. aureus [95]. Nowadays, the 
Table 1 Prevalence of MRSA in veterinarian personnel and animal workers reported in studies conducted worldwide

\begin{tabular}{|c|c|c|c|c|c|}
\hline Study & Year conducted & Country & Prevalence & $\mathrm{N}$ & Population \\
\hline (Chen et al., 2020) [65] & 2019 & China & $31.71 \%$ & 41 & Veterinarians (veterinary hospitals) \\
\hline (Schmidt et al., 2020) [66] & Aug 2018-Jan 2019 & Switzerland & $7.07 \%$ & 99 & $\begin{array}{l}\text { Veterinary personnel from animal companion } \\
\text { clinics }\end{array}$ \\
\hline (Kittl et al., 2020) [67] & 2017 & Switzerland & $5.13 \%$ & 156 & Farmers \\
\hline (Kittl et al., 2020) [67] & 2017 & Switzerland & $6.60 \%$ & 212 & Veterinarians \\
\hline (Neradova et al., 2020) [68] & 2017 & Czech Republic & $6.72 \%$ & 134 & Veterinary personnel \\
\hline (Taus et al., 2019) [69] & 2017 & Austria & $13.40 \%$ & 261 & Veterinarians \\
\hline (Taus et al., 2019) [69] & 2017 & Austria & $38.30 \%$ & 47 & Swine veterinarians \\
\hline (Taus et al., 2019) [69] & 2017 & Austria & $7.90 \%$ & 214 & Non-swine veterinarians \\
\hline (Verkola et al., 2019) [70] & 2016 & Finland & $0.30 \%$ & 320 & Veterinarians \\
\hline (Tabatabaei et al., 2019) [71] & Nov 2012-Mar 2013 & Iran & $4.00 \%$ & 50 & Veterinary personnel \\
\hline (Sun et al., 2017) [72] & 2012 & USA & $9.50 \%$ & 66 & Swine veterinarians \\
\hline (Wang et al., 2017) [61] & Nov 2013-Nov 2014 & China & $5.10 \%$ & 335 & Farmers and veterinarians (pig-related workers) \\
\hline (Mroczkowska et al., 2017) [60] & Aug 2010-Nov 2012 & Poland & $3.20 \%$ & 283 & Pig farmers \\
\hline (Mroczkowska et al., 2017) [60] & Aug 2010-Nov 2012 & Poland & $10.50 \%$ & 38 & Veterinarians \\
\hline (Post et al., 2017) [73] & 2013 & Worldwide & $5.00 \%$ & 60 & Veterinary surgeons \\
\hline (Walter et al., 2016) [74] & $2008-2009$ & Germany & $9.00 \%$ & 695 & Veterinarian attending to different species \\
\hline (Walter et al., 2016) [74] & $2008-2009$ & Germany & $8.53 \%$ & 516 & Veterinarian in contact with cattle \\
\hline (Walter et al., 2016) [74] & $2008-2009$ & Germany & $14.52 \%$ & 365 & Veterinarian in contact with pigs \\
\hline (Steinman et al., 2015) [75] & 2012 & Israel & $16.90 \%$ & 59 & Staff members of a veterinary hospital \\
\hline (Verkade et al., 2014) [76] & Jul 2008-Dec 2009 & The Netherlands & $44.00 \%$ & 137 & Veterinarians \\
\hline (Wettstein Rosenkranz et al., 2014) [77] & 2012 & Switzerland & $2.73 \%$ & 146 & Veterinarians of small animals \\
\hline (Wettstein Rosenkranz et al., 2014) [77] & 2012 & Switzerland & $6.45 \%$ & 31 & Veterinarians of large animals \\
\hline (Wettstein Rosenkranz et al., 2014) [77] & 2012 & Switzerland & $4.50 \%$ & 111 & Veterinarians of general practice \\
\hline (Ishihara et al., 2014) [78] & 2008 & Japan & $22.90 \%$ & 96 & Veterinarian for dog and cats \\
\hline (Ishihara et al., 2014) [78] & 2008 & Japan & $10.00 \%$ & 70 & Veterinarian technician for dog and cats \\
\hline (Paterson et al., 2013) [79] & 2011 & UK & $2.60 \%$ & 307 & Cattle Veterinarians (Mostly) \\
\hline (Boost et al., 2013) [80] & Not specified & Hong Kong, China & $5.60 \%$ & 300 & Pork butchers \\
\hline (Schwaber et al., 2013) [81] & 2010 & Israel & $50.00 \%$ & 20 & Full-time equine staff \\
\hline (Schwaber et al., 2013) [81] & 2010 & Israel & $4.55 \%$ & 22 & Community equine veterinarians \\
\hline (Garcia-Graells et al., 2012) [82] & 2010 & Belgium & $8.90 \%$ & 105 & Livestock veterinarians \\
\hline (Garcia-Graells et al., 2012) [82] & 2010 & Denmark & $2.10 \%$ & 97 & Livestock veterinarians \\
\hline (Paul et al., 2011) [83] & 2010 & Italy & $1.60 \%$ & 128 & Small animal dermatologists \\
\hline (Jordan et al., 2011) [84] & 2009 & Australia & $4.80 \%$ & 250 & Dog and cat veterinarians \\
\hline (Jordan et al., 2011) [84] & 2009 & Australia & $21.35 \%$ & 89 & Horse veterinarians \\
\hline (Jordan et al., 2011) [84] & 2009 & Australia & $8.33 \%$ & 12 & Pig veterinarians \\
\hline (Zhang et al., 2011) [85] & $2008-2009$ & China & $1.96 \%$ & 51 & Small animal veterinary staff \\
\hline (Horgan et al., 2011) [86] & 2008 & Ireland & $2.00 \%$ & 100 & Pig Health Society Symposium attendees \\
\hline (Ben Slama et al., 2011) [87] & $2008-2009$ & Tunisia & $1.20 \%$ & 83 & $\begin{array}{l}\text { Veterinarian students or staff, farmers and } \\
\text { abattoir workers }\end{array}$ \\
\hline (Ishihara et al., 2010) [88] & 2007 & Japan & $25.00 \%$ & 20 & Veterinarians \\
\hline (Ishihara et al., 2010) [88] & 2008 & Japan & $23.50 \%$ & 34 & Veterinarians \\
\hline (Ishihara et al., 2010) [88] & 2007 & Japan & $11.96 \%$ & 92 & Veterinary personnel \\
\hline (Ishihara et al., 2010) [88] & 2008 & Japan & $7.87 \%$ & 127 & Veterinary personnel \\
\hline (Huber et al., 2010) [62] & 2009 & Switzerland & $0.00 \%$ & 148 & Pig farmers \\
\hline (Huber et al., 2010) [62] & 2009 & Switzerland & $3.01 \%$ & 133 & Veterinarians \\
\hline (Huber et al., 2010) [62] & 2009 & Switzerland & $0.00 \%$ & 179 & Slaughterhouse employees \\
\hline (Burstiner et al., 2010) [89] & 2008 & USA & $17.30 \%$ & 341 & Veterinary surgeons and technicians \\
\hline (Boost et al., 2011) [90] & Not specified & Hong Kong, China & $0.67 \%$ & 150 & Veterinary personnel \\
\hline (Heller et al., 2009) [91] & Not specified & Scotland, UK & $3.13 \%$ & 64 & Small animal hospital staff members \\
\hline
\end{tabular}


Table 1 (continued)

\begin{tabular}{|c|c|c|c|c|c|}
\hline Study & Year conducted & Country & Prevalence & $\mathbf{N}$ & Population \\
\hline (Zemlicková et al., 2009) [92] & 2008 & Czech Republic & $0.70 \%$ & 280 & $\begin{array}{l}261 \text { Veterinary professionals (veterinarian and } \\
\text { technician); } 19 \text { Pharmacist }\end{array}$ \\
\hline (Meemken et al., 2008) [93] & 2007 & Germany & $23.26 \%$ & 86 & $\begin{array}{l}\text { Veterinarians, laboratory personnel and meat } \\
\text { inspection personnel }\end{array}$ \\
\hline (Moodley et al., 2008) [94] & Aug 2006-Feb 2007 & Denmark & $3.90 \%$ & 231 & Veterinarians (small and large animals) \\
\hline (Moodley et al., 2008) [94] & Aug 2006-Feb 2008 & Denmark & $0.00 \%$ & 98 & Farmers \\
\hline
\end{tabular}

transmission of CC398 from animals to humans is considered difficult, as this strain does not usually persist in humans [50]. Nonetheless, this paradigm is changing and fatal cases of infection in humans with CC398 have been reported [56]. Other strains of MRSA, such as CC97 which is transmitted between pigs and cattle in Italy, affect more than one animal species [96]. In addition, colonisation with MRSA is dependent on the duration of animal contact and the strain involved [50]. In this sense, farm workers who are frequently in close contact with animals are at a higher risk of acquiring MRSA, even more so than veterinarians whose duties include drug administration and necropsies. The age of the animals is also considered a risk factor. Younger pigs are more likely to be colonized with MRSA [64] and it is interesting that these younger pigs generally require the most intensive handling and care.

The higher prevalence of MRSA colonisation in veterinarians from countries such as the Netherlands, Germany and USA can be explained by their having large pig herd sizes and intensive production systems. Although having smaller herd sizes, Austria also reported a higher prevalence of MRSA colonisation in swine veterinarians compared with non-swine veterinarians. However, veterinary personnel from clinics and hospitals for small animals or horses also showed a high prevalence of MRSA colonisation worldwide. A study conducted in 2008 in Ireland reported a low prevalence of MRSA colonisation in pig industry personnel, and none of the samples found were CC398 MRSA [86]. After the first reported case of CC398 MRSA (spa t011) in 2012, other incidents of CC398 MRSA colonisation have been reported on two Irish farms and in a veterinarian [97]. This demonstrates that natural barriers, such as Ireland's island status, are not sufficient in preventing MRSA spread unless they go in hand with a surveillance program which controls animal importations and strict on-farm biosecurity measures for personnel visiting or returning from abroad. Switzerland also reported a low prevalence for MRSA colonisation

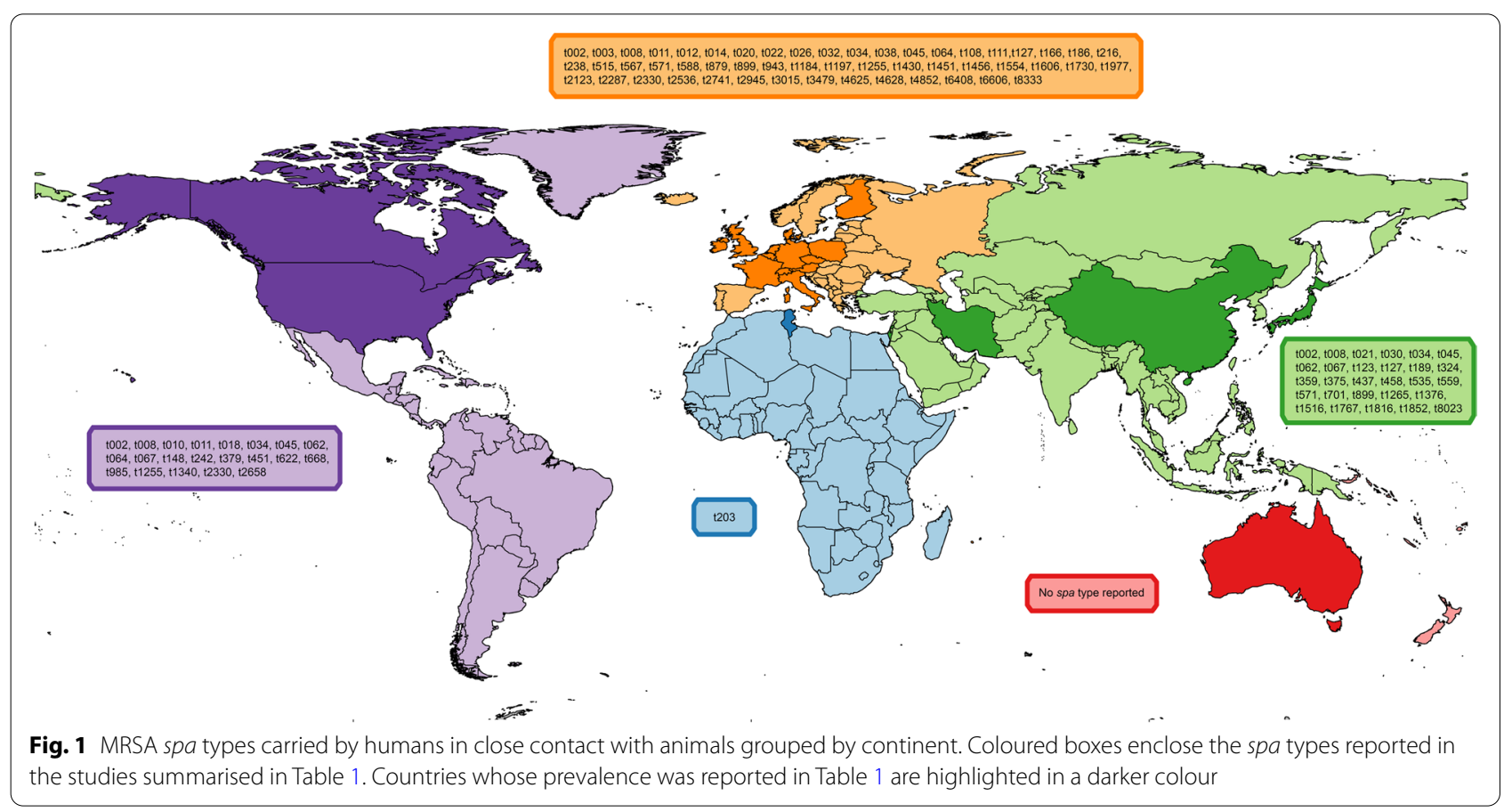


among veterinarians, pig farmers and slaughterhouse employees in 2009. Over a decade later, the prevalence in veterinarians has increased along with the prevalence of MRSA in Swiss livestock [67], despite ongoing efforts to reduce antimicrobial usage [64]. This increase seems to be due to the spread of spa t034 among the swine herd there. The prevalence of MRSA in the Swiss pig population further increased with the rapid spread of spa t011, but this strain seems to be poorly adapted to colonising humans. Swiss cattle are also colonised by MRSA, but its increase in prevalence has been slower. As the importation of pigs into Switzerland is low and combined with the fact that many farms there have mixed livestock enterprises (pigs, cattle, poultry and/ or horses) could suggest that another species other than pigs may have acted as a reservoir of MRSA there.

\section{Shouldn't reduced antimicrobial usage decrease the prevalence of MRSA in farm settings?}

Most European countries reduced antimicrobial consumption in the period from 2010 to 2017 [98]. However, the prevalence of MRSA in animals has not decreased in these countries, but rather, in some (Finland, Spain and Switzerland) it has increased while in others it has remained stable (Germany and Norway) [99]. A possible explanation for this could be that once MRSA becomes endemic in a setting, it is difficult for other bacteria to compete and displace resistant strains. The selective pressure of antibiotic use allows MRSA to thrive, whereas it is more difficult for the non-resistant bacteria to survive. In theory, if antibiotics are no longer used, other susceptible strains of $S$. aureus or other bacteria should out-compete MRSA due to the fitness cost of expressing the resistance genes. However, some MRSA strains possess resistance genes with low fitness-costs that allow them to compete and dominate hospital settings [100]. In a controlled environment, such as a hospital setting, reduced antimicrobial consumption in humans has proven effective in reducing MRSA presence [101], but these strategies do not necessarily decrease bacterial resistance [102]. Along with reducing antimicrobial use, what could be a more effective strategy for reducing MRSA levels in a setting is to frequently change the class of the antibiotics used $[102,103]$. In this scenario, MRSA will not have a selective advantage over methicillin-susceptible strains if both are susceptible or resistant to the same prescribed antibiotic, and due to competition, susceptible strains will increase in circulation in detriment of MRSA. MRSA can also revert spontaneously to a susceptible strain if there is no selective pressure from antibiotics [104]. Nonetheless, if only the MRSA strain is resistant to the prescribed antibiotic, MRSA circulation will be enhanced. This frequent change in the class of antibiotic treatment has the potential to eliminate the bacterium, but it also has the risk of selecting for multi-drug resistance if treated strains are susceptible, as some of them may develop new resistances and survive the next change in antibiotic, accumulating resistance.

Another possible explanation as to why MRSA is increasing in prevalence on livestock farms is that humans can act as a reservoir for MRSA [105]. Research usually focuses on MRSA strains that are transmitted from animals to humans and the duration of the colonisation. However, colonised humans are an important source for introducing MRSA onto the farm setting [106]. As an example, one of the outbreaks of MRSA in Norway happened through the introduction onto farms of CC1 MRSA, described mainly as an HA-MRSA, by a farm worker and spread through animal trading between farms [25]. Although $\mathrm{CC} 1$ has been described mainly as an HA-MRSA, it is not uncommon to find it in animals [107]. Therefore, we consider that the study of the transmission of MRSA from humans to animals should receive more attention, as it is likely that the spread of MRSA in livestock within and across countries may be due to animal contact with infected farm workers and/or veterinarians.

\section{Alternative treatments for MRSA colonisation in animals}

There is increasing concern worldwide regarding antimicrobial resistance (AMR) because fewer options for treating immunocompromised patients will be available if AMR is not reduced. In 2016, the United Nations (UN) General Assembly discussed strategies for fighting AMR from a joint perspective (www.un.org/pga/70/events/ high-level-meeting-on-antimicrobial-resistance/). One of the greatest challenges that human health faces is the appearance of bacteria resistant to last resort antibiotics for humans and livestock species, such as vancomycinresistant $S$. aureus $[108,109]$. It is important to note that some of the strategies to avoid the appearance of these new resistances include the elimination of last resort drugs from use in animal production. This policy is being applied in China, the main consumer of antimicrobials for veterinary use, although some European countries still retain the use of these drugs in farm settings [110]. Alongside the need to reduce antibiotic usage, there has been an increase in the number of studies looking for alternative treatments to control/prevent MRSA colonisation.

Probiotics are one of the alternatives to antibiotics for the treatment and control of MRSA that have received most attention. The abundance of certain bacteria, such as lactic acid bacteria (Lactobacillus spp.), is negatively correlated with S. aureus abundance [111], which suggests that these bacteria may inhibit MRSA growth. The 
production of hydrogen peroxide $\left(\mathrm{H}_{2} \mathrm{O}_{2}\right)$ by vaginal lactobacilli has been suggested as a possible bacteriostatic mechanism for reducing S. aureus levels [112, 113]. However, the low concentrations of $\mathrm{O}_{2}$ found in the vaginal environment, which is required for $\mathrm{H}_{2} \mathrm{O}_{2}$ production, suggests that the antimicrobial properties of Lactobacillus spp. may be linked to production of another substance (e.g. lactic acid) which they produce in hypoxic environments [114]. Another mechanism in which Lactobacillus spp. might inhibit $S$. aureus colonisation is through the secretion of a biosurfactant that impedes the adhesion of S. aureus to surfaces [115]. Although most of the studies concerning the use of bacteria to control $S$. aureus have been performed in vitro, some have been conducted in vivo in mice and humans. The oral administration of Lactobacillus spp. reduced $S$. aureus carriage in the gastrointestinal tract of humans [116]. Whether consumed orally or administered in conjunction with nasal sprays, lactobacilli have also been used with the purpose of eradicating long-term nasal carriage of MRSA in humans. The mode of action of the lactobacilli here is thought to be mediated through stimulation of the upper respiratory immune system of the host. Nonetheless, such treatments have not been completely effective $[117,118]$.

With the global trend towards reducing antimicrobial usage in livestock, the use of probiotics in food-producing animals seems a viable alternative. The addition of probiotics, such as Bacillus subtilis, to feed can improve feed efficiency in pigs whilst these probiotics also possess in vitro inhibitory activity over S. aureus [119]. The action of $B$. subtilis against $S$. aureus is mediated through the use of fengycins, a lipopeptide that inhibits quorum sensing in S. aureus colonies, impairing their ability to perceive their population density and act in response with genetic adaptations [120]. In staphylococcal infections, quorum sensing regulates, among others, toxin production, the expression of colonisation factors and biofilm formation [121]. Of note, the presence of B. subtillis in the human intestine was associated with the absence of $S$. aureus not only in the intestine, but also in the nasal passage, even though B. subtilis was seldom found colonising the airways of subjects [120].

Bacteria from various environments have been evaluated to 'mine' new probiotics with bacteriostatic activity against MRSA. For example, in an Irish study, Streptomyces sp. myrophorea recovered from soil has been reported to have activity against several pathogens, including MRSA [122]. Other approaches have studied the microbial ecology of the host using $16 \mathrm{~S}$ rRNA gene sequencing and considered the co-abundance of the bacteria present to analyse those species positively and negatively correlated with MRSA. In one such study, S. aureus colonisation was seldom found in the nasal passages of pigs when other staphylococci species (S. sciuri, S. cohnii, and S. saprophyticus) were present [123].

Another possible alternative for reducing MRSA carriage is the use of bacteriophage therapies. The treatment of staphylococcal skin lesions was the target of one of the first bacteriophage therapies used [124]. However, phage therapies were relegated to a second place in Western medicine a few decades later because of the wide-spread use of antibiotics [125]. In recent years, phage therapy research has again resurfaced to find alternatives to antimicrobial treatments. Clinical trials in mice have shown that bacteriophage administration can protect against lethal MRSA infections and reduce $S$. aureus levels in the nasal passages [126, 127]. Although promising, clinical trials with bacteriophage therapies are still rare due to a number of challenges, including the possibility of MRSA acquiring resistance to the phage, side effects of bacterial lysis, governmental constraints and public reticence towards administration of a self-replicating agent [125, 128].

\section{Eradication strategies}

MRSA can be eradicated from hospitals by implementing strict hygiene measures and controlling the environment. For instance, 'search and destroy' policies were applied in the Netherlands and Denmark reducing the spread of both HA- and CA-MRSA in health-care settings $[129,130]$. In these strategies, screening for MRSA carriage is performed on patients and health-care workers. Thereafter, all the individuals positive for MRSA are isolated and treated, when possible, in order to eliminate MRSA carriage. Similar preventive measures have been applied in the U.S., such as in the REDUCE-MRSA trial, which reported a $37 \%$ reduction of MRSA carriage when universal decolonisation was practiced on all patients in the same intensive care units (ICUs) through intranasal mupirocin application and bathing with cloths impregnated in chlorhexidine [131]. Measures for the prevention and control of MRSA infections and the interruption of its transmission in U.S. hospital settings were successful in reducing the incidence of HA-MRSA bacteraemia in the last few decades [132]. However, the rate of decline in HA-MRSA infections has slowed since 2012 in the U.S., while at the same time the incidence of CA-MRSA infections has increased slightly. This suggests the need for new preventive measures [132].

In 2013, Norway commenced a national control strategy to eradicate MRSA from pig farms [40]. The strategy involves the annual screening of all pig herds but also a surveillance program of the human population, following the "One Health" approach. Information from reported human MRSA cases in hospitals allows the tracing of 
MRSA spread across Norway. Furthermore, introduction of MRSA into pig herds in Norway from abroad can easily be traced since Norwegian pig production is a particularly closed system, with few stock importations [40]. The Norwegian eradication campaign follows a series of steps, starting with an annual screening of the pig population. When a farm is found to be positive for MRSA, trade in live animals is restricted, and farms are depopulated followed by thorough washing and disinfection. Once confirmed free of MRSA, the farm is re-stocked with pigs from MRSA negative herds. Even then, animals from the restocked farm are screened again before reaching the slaughterhouse to assess the success of MRSA eradication [40]. As part of the programme, farm staff and their relatives are screened for MRSA carriage. There are increased restrictions on visiting Norwegian pig farms, especially if the visitor is from abroad, to help limit potential colonisation. It would seem that this strict, expensive and time-consuming eradication programme is effective as the prevalence of MRSA in Norwegian pigs has been kept low $(<0.5 \%)$ [99].

\section{Suggestions to prevent MRSA introduction onto farms}

The introduction of MRSA onto a farm can occur via different routes. The most important of these being the movement of MRSA colonised animals from one farm to another, direct contact with colonised humans and through animal contact with contaminated transport vehicles [38-40]. For this reason, good external biosecurity protocols should be adhered to when importing live animals onto a farm. Stock to be introduced should only be purchased from MRSA-negative herds. They should be quarantined at $550 \mathrm{~m}$ from the rest of the herd for a minimum period of 6 weeks as it has been shown that MRSA can be airborne and spread in this manner [42, 43, 133]. Animals should be screened for MRSA during quarantine and only allowed join the main herd when shown to be MRSA-negative. Gloves should be worn when animals are handled and all humans working or visiting the farm should shower in before entering and shower out when exiting the farm [36]. The number of visitors entering the farm should be kept to a minimum, but when necessary, visitors should not have been on another farm in the previous $48 \mathrm{~h}$ as LA-MRSA can still be carried during that period [134]. Furthermore, farm visitors should wear masks to reduce transmission to the herd [135]. Meat products should not be permitted on the farm, as MRSA can also survive in them $[45,46]$.

Antimicrobial use on farms should be minimised. When MRSA first enters a farm, antimicrobial use helps to select for MRSA strains, to the detriment of the nonresistant strains [39]. In a model to assess the efficacy of interventions on the spread of MRSA on Danish pig farms, reducing antimicrobial use, restricting movement of animals and reducing human transmission were predicted to be highly effective when introduced in a low MRSA prevalence area [106]. However, these measures need to be implemented before an endemic situation occurs, otherwise much stricter control measures, like those in Norway, will be required, such as culling a percentage of MRSA positive herds.

\section{Conclusion}

Despite reduced antimicrobial usage in European animal production in recent years, the prevalence of MRSA in farm animals has not declined. It is therefore likely that, MRSA persists in other reservoirs, such as in humans (i.e. farm workers and veterinarians). In highly colonised farms, strategies involving reducing the reliance on antibiotic usage and the frequent change of antibiotic classes used should be considered for reducing MRSA levels. Control and treatment strategies such as, strict preventive biosecurity measures, selective probiotic feeding and MRSA eradication programmes should be used to prevent MRSA entering a farm, reduce MRSA carriage and eradicate MRSA from infected farms, respectively. Doing so will help to prevent a future where antibiotics are no longer an effective treatment for MRSA infections in animals and humans.

\section{Abbreviations}

AMR: Antimicrobial resistance; blaZ: B-lactamase gene; CA-MRSA: Communityacquired MRSA; CC: Clonal complex; $\mathrm{H}_{2} \mathrm{O}_{2}$ : Hydrogen peroxide; HA-MRSA: Hospital-acquired MRSA; ICUs: Intensive care units; LA-MRSA: Livestock-associated MRSA; MGE: Mobile genetic elements; MLST: Multilocus sequence typing; MLVA: Multilocus VNTR analysis; MRSA: Methicillin-resistant S. aureus; PBP:

Penicillin-binding proteins; PBP2a: Penicillin-binding protein 2a; PFGE: Pulsedfield gel electrophoresis; SCCmec: Staphylococcal cassette chromosome mec; spa: S. aureus surface protein A; ST: Sequence type; UN: United Nations; VNTR: Variable-number tandem repeat.

\section{Acknowledgements \\ Not applicable.}

\section{Authors' contributions}

DC and PL conceived, drafted, and wrote the manuscript. DC prepared the table and figure. PL critically reviewed the manuscript. All authors approved the final version of the manuscript.

\section{Funding}

The ExcludeMRSA project is funded by the Irish Health Research Board (HRB), Grant Reference: JPIAMR-2017-1-A.

\section{Availability of data and materials} Not applicable.

\section{Declarations}

Ethics approval and consent to participate Not applicable. 


\section{Consent for publication \\ Not applicable.}

\section{Competing interests}

The authors declare that they have no competing interests.

Received: 5 May 2021 Accepted: 13 July 2021

Published online: 06 August 2021

\section{References}

1. Stratton CW. Coagulase-positive staphylococci. Infect Control. 1982;3:79-81.

2. Huebner J, Goldmann DA. Coagulase-negative staphylococci: role as pathogens. Annu Rev Med. 1999;50:223-36. https://doi.org/10.1146/ annurev.med.50.1.223.

3. Wertheim HFL, Melles DC, Vos MC, van Leeuwen W, van Belkum A, Verbrugh HA, et al. The role of nasal carriage in Staphylococcus aureus infections. Lancet Infect Dis. 2005:5:751-62. https://doi.org/10.1016/ S1473-3099(05)70295-4

4. Tong SYC, Davis JS, Eichenberger E, Holland TL, Fowler VG. Staphylococcus aureus infections: epidemiology, pathophysiology, clinical manifestations, and management. Clin Microbiol Rev. 2015;28:603-61. https://doi.org/10.1128/CMR.00134-14.

5. Lowy FD. Staphylococcus aureus infections. N Engl J Med. 1998;339:520-32. https://doi.org/10.1056/NEJM199808203390806.

6. van Belkum A, Verkaik NJ, de Vogel CP, Boelens HA, Verveer J, Nouwen $J$, et al. Reclassification of Staphylococcus aureus nasal carriage types. J Infect Dis. 2009;199:1820-6. https://doi.org/10.1086/599119.

7. Barber M. The incidence of penicillin-sensitive variant colonies in penicillinase-producing strains of Staphylococcus pyogenes. J Gen Microbiol. 1949:3:274-81. https://doi.org/10.1099/00221287-3-2-274.

8. Novick RP. Analysis by transduction of mutations affecting penicillinase formation in Staphylococcus aureus. J Gen Microbiol. 1963;33:121-36. https://doi.org/10.1099/00221287-33-1-121.

9. Novick RP, Bouanchaud D. The problems of drug-resistant pathogenic bacteria. Extrachromosomal nature of drug resistance in Staphylococcus aureus. Ann N Y Acad Sci. 1971;182:279-94.

10. Lowy FD. Antimicrobial resistance: the example of Staphylococcus aureus. J Clin Invest. 2003;111:1265-73. https://doi.org/10.1172/JCI18 535.

11. Ghuysen JM. Molecular structures of penicillin-binding proteins and beta-lactamases. Trends Microbiol. 1994;2:372-80.

12. Jevons MP. “Celbenin" - resistant Staphylococci. BMJ. 1961;1:124-5. https://doi.org/10.1136/bmj.1.5219.124-a.

13. Barber M. Methicillin-resistant staphylococci. J Clin Pathol. 1961;14:385-93.

14. Hartman BJ, Tomasz A. Low-affinity penicillin-binding protein associated with beta-lactam resistance in Staphylococcus aureus. J Bacteriol. 1984;158:513-6. https://doi.org/10.1017/CBO9781107415324.004.

15. Saravolatz LD, Pohlod DJ, Arking LM. Community-acquired methicillinresistant Staphylococcus aureus infections: a new source for nosocomial outbreaks. Ann Intern Med. 1982;97:325-9.

16. Centers for Disease Control and Prevention (CDC). Four pediatric deaths from community-acquired methicillin-resistant Staphylococcus aureus - Minnesota and North Dakota, 1997-1999. MMWR Morb Mortal Wkly Rep. 1999;48:707-10.

17. Herold BC, Immergluck LC, Maranan MC, Lauderdale DS, Gaskin RE, Boyle-Vavra S, et al. Community-acquired methicillin-resistant Staphylococcus aureus in children with no identified predisposing risk. JAMA. 1998;279:593-8.

18. Chambers HF, Deleo FR. Waves of resistance: Staphylococcus aureus in the antibiotic era. Nat Rev Microbiol. 2009;7:629-41. https://doi.org/10. 1038/nrmicro2200.

19. Voss A, Loeffen F, Bakker J, Klaassen C, Wulf M. Methicillin-resistant Staphylococcus aureus in pig farming. Emerg Infect Dis. 2005;11:19656. https://doi.org/10.3201/eid1112.050428.

20. Reischl U, Frick J, Hoermansdorfer S, Melzl H, Bollwein M, Linde HJ, et al. Single-nucleotide polymorphism in the SCCmec-orfX junction distinguishes between livestock-associated MRSA CC398 and human epidemic MRSA strains. Euro Surveill. 2009;14:1-8.

21. Stefani S, Chung DR, Lindsay JA, Friedrich AW, Kearns AM, Westh $\mathrm{H}$, et al. Meticillin-resistant Staphylococcus aureus (MRSA): global epidemiology and harmonisation of typing methods. Int J Antimicrob Agents. 2012;39:273-82. https://doi.org/10.1016/j.ijantimicag.2011.09.030 (Elsevier B.V.).

22. Struelens MJ, Hawkey PM, French GL, Witte W, Tacconelli E. Laboratory tools and strategies for methicillin-resistant Staphylococcus aureus screening, surveillance and typing: state of the art and unmet needs. Clin Microbiol Infect. 2009;15:112-9. https://doi.org/10.1111/j.1469$0691.2009 .02698 x$

23. Abd El-Hamid MI, Bendary MM, Merwad AMA, Elsohaby I, Mohammad Ghaith D, Alshareef WA. What is behind phylogenetic analysis of hospital-, community- and livestock-associated methicillin-resistant Staphylococcus aureus? Transbound Emerg Dis. 2019;66:1506-17. https://doi.org/10.1111/tbed.13170.

24. Bal AM, Coombs GW, Holden MTG, Lindsay JA, Nimmo GR, Tattevin P, et al. Genomic insights into the emergence and spread of international clones of healthcare-, community- and livestock-associated meticillinresistant Staphylococcus aureus: Blurring of the traditional definitions. J Glob Antimicrob Resist Taibah Univ. 2016;6:95-101. https://doi.org/10. 1016/j.jgar.2016.04.004.

25. Elstrøm P, Grøntvedt CA, Gabrielsen C, Stegger M, Angen Ø, Åmdal $\mathrm{S}$, et al. Livestock-associated MRSA CC1 in Norway; Introduction to pig farms, zoonotic transmission, and eradication. Front Microbiol. 2019:10:139. https://doi.org/10.3389/fmicb.2019.00139.

26. David MZ, Daum RS. Community-associated methicillin-resistant Staphylococcus aureus: epidemiology and clinical consequences of an emerging epidemic. Clin Microbiol Rev. 2010;23:616-87. https://doi. org/10.1128/CMR.00081-09.

27. Rossi G, Cerquetella M, Attili AR. Amphixenosic aspects of Staphylococcus aureus infection in man and animals. In: Bagnoli F, Rappuoli R, Grandi G, editors. Staphylococcus aureus: Microbiology, Pathology, Immunology, Therapy and Prophylaxis. Cham: Springer International Publishing; 2016. p. 297-323. https://doi.org/10.1007/82_2016_2.

28. Devriese LA, Van Damme LR, Fameree L. Methicillin (cloxacillin)-resistant Staphylococcus aureus strains isolated from bovine mastitis cases. Zentralbl Veterinarmed B. 1972;19:598-605. https://doi.org/10.1111/j. 1439-0450.1972.tb00439x.

29. Moreno-Grúa E, Pérez-Fuentes S, Muñoz-Silvestre A, Viana D, Fernández-Ros AB, Sanz-Tejero $C$, et al. Characterization of livestock-associated methicillin-resistant Staphylococcus aureus isolates obtained from commercial rabbitries located in the Iberian Peninsula. Front Microbiol. 2018;9:1812. https://doi.org/10.3389/ fmicb.2018.01812.

30. Weese JS. Methicillin-resistant Staphylococcus aureus in animals. ILAR J. 2010;51:233-44. https://doi.org/10.1093/ilar.51.3.233.

31. Werckenthin C, Cardoso M, Martel JL, Schwarz S. Antimicrobial resistance in staphylococci from animals with particular reference to bovine Staphylococcus aureus, porcine Staphylococcus hyicus, and canine Staphylococcus intermedius. Vet Res. 2001;32:341-62. https://doi.org/ 10.1051/vetres:2001129

32. Baptiste KE, Williams K, Willams NJ, Wattret A, Clegg PD, Dawson S, et al. Methicillin-resistant staphylococci in companion animals. Emerg Infect Dis. 2005;11:1942-4. https://doi.org/10.3201/eid1112.050241.

33. Ruiz-Ripa L, Gómez P, Alonso CA, Camacho MC, de la Puente J, Fernández-Fernández R, et al. Detection of MRSA of lineages CC130-mecC and CC398-mecA and Staphylococcus delphini-Inu(A) in magpies and cinereous vultures in Spain. Microb Ecol. 2019;78:409-15. https://doi. org/10.1007/s00248-019-01328-4.

34. Vautor E, Abadie G, Guibert J-M, Huard C, Pépin M. Genotyping of Staphylococcus aureus isolated from various sites on farms with dairy sheep using pulsed-field gel electrophoresis. Vet Microbiol. 2003;96:69_ 79. https://doi.org/10.1016/S0378-1135(03)00207-4.

35. Hanselman BA, Kruth SA, Rousseau J, Weese JS. Coagulase positive staphylococcal colonization of humans and their household pets. Can Vet J. 2009;50:954-8.

36. EFSA Panel on Biological Hazards. Assessment of the Public Health significance of meticillin resistant Staphylococcus aureus (MRSA) in 
animals and foods. EFSA J. 2009;993:1-73. https://doi.org/10.2903/j.efsa. 2009.993.

37. Boyce JM, Potter-Bynoe G, Chenevert C, King T. Environmental contamination due to methicillin-resistant Staphylococcus aureus: possible infection control implications. Infect Control Hosp Epidemiol. 1997;18:622-7.

38. van Duijkeren E, Ikawaty R, Broekhuizen-Stins MJ, Jansen MD, Spalburg EC, de Neeling AJ, et al. Transmission of methicillin-resistant Staphylococcus aureus strains between different kinds of pig farms. Vet Microbiol. 2008;126:383-9. https://doi.org/10.1016/j.vetmic.2007.07.021

39. Broens EM, Espinosa-Gongora C, Graat EAM, Vendrig N, Van Der Wolf PJ, Guardabassi L, et al. Longitudinal study on transmission of MRSA CC398 within pig herds. BMC Vet Res. 2012;8:58. https://doi.org/10.1186/ 1746-6148-8-58

40. Grøntvedt CA, Elstrøm P, Stegger M, Skov RL, Skytt Andersen P, Larssen KW, et al. Methicillin-resistant Staphylococcus aureus CC398 in humans and pigs in Norway: a "One Health" perspective on introduction and transmission. Clin Infect Dis. 2016;63:1431-8. https://doi.org/10.1093/ $\mathrm{cid} / \mathrm{ciw} 552$

41. Feld L, Bay $H$, Angen $\varnothing$, Larsen AR, Madsen AM. Survival of LA-MRSA in dust from swine farms. Ann Work Expo Heal. 2018;62:147-56. https:// doi.org/10.1093/annweh/wxx108.

42. Seedorf J, Schulz J, Hartung J. Outdoor measurements of airborne emission of staphylococci from a broiler barn and its predictability by dispersion models. Environ Expo Heal WIT Transact Ecolx Environment. 2005:85:33-42. https://doi.org/10.2495/EEH050041

43. Shiomori T, Miyamoto H, Makishima K. Significance of airborne transmission of methicillin-resistant Staphylococcus aureus in an otolaryngology-head and neck surgery unit. Arch Otolaryngol Head Neck Surg. 2001;127:644-8

44. Bos MEH, Verstappen KM, van Cleef BAGL, Dohmen W, Dorado-García A, Graveland $\mathrm{H}$, et al. Transmission through air as a possible route of exposure for MRSA. J Expo Sci Environ Epidemiol. 2016;26:263-9. https://doi. org/10.1038/jes.2014.85

45. Pondit A, Haque ZF, Sabuj AAM, Khan MSR, Saha S. Characterization of Staphylococcus aureus isolated from chicken and quail eggshell. J Adv Vet Anim Res. 2018;5:466-71. https://doi.org/10.5455/javar.2018.e300.

46. Ge B, Mukherjee S, Hsu C-H, Davis JA, Tran TTT, Yang Q, et al. MRSA and multidrug-resistant Staphylococcus aureus in U.S. retail meats, 2010-2011. Food Microbiol. 2017;62:289-97. https://doi.org/10.1016/j. fm.2016.10.029.

47. Weinert LA, Welch JJ, Suchard MA, Lemey P, Rambaut A, Fitzgerald JR. Molecular dating of human-to-bovid host jumps by Staphylococcus aureus reveals an association with the spread of domestication. Biol Lett. 2012;8:829-32. https://doi.org/10.1098/rsbl.2012.0290.

48. Armand-Lefevre L, Ruimy R, Andremont A. Clonal comparison of Staphylococcus aureus isolates from healthy pig farmers, human controls, and pigs. Emerg Infect Dis. 2005;1 1:711-4. https://doi.org/10. 3201/eid1105.040866.

49. van Loo I, Huijsdens X, Tiemersma E, de Neeling A, van de SandeBruinsma N, Beaujean D, et al. Emergence of methicillin-resistant Staphylococcus aureus of animal origin in humans. Emerg Infect Dis. 2007:13:1834-9. https://doi.org/10.3201/eid1312.070384.

50. Graveland H, Wagenaar JA, Bergs K, Heesterbeek H, Heederik D. Persistence of livestock associated MRSA CC398 in humans is dependent on intensity of animal contact. PLoS ONE. 2011;6: e16830. https://doi.org/ 10.1371/journal.pone.0016830.

51. Azarian T, Daum RS, Petty LA, Steinbeck JL, Yin Z, Nolan D, et al. Intrahost evolution of methicillin-resistant Staphylococcus aureus USA300 among individuals with reoccurring skin and soft-tissue infections. J Infect Dis. 2016;214:895-905. https://doi.org/10.1093/infdis/jiw242.

52. Graveland H, Wagenaar JA, Heesterbeek H, Mevius D, van Duijkeren E, Heederik D. Methicillin resistant Staphylococcus aureus ST398 in veal calf farming: human MRSA carriage related with animal antimicrobial usage and farm hygiene. PLoS One. 2010;5:e10990. https://doi.org/10. 1371/journal.pone.0010990.

53. Feingold BJ, Silbergeld EK, Curriero FC, van Cleef BAGL, Heck MEOC, Kluytmans JAJW. Livestock density as risk factor for livestock-associated methicillin-resistant Staphylococcus aureus, the Netherlands. Emerg Infect Dis. 2012;18:1841-9. https://doi.org/10.3201/eid1811.111850.
54. Casey JA, Curriero FC, Cosgrove SE, Nachman KE, Schwartz BS. Highdensity livestock operations, crop field application of manure, and risk of community-associated methicillin-resistant Staphylococcus aureus infection in Pennsylvania. JAMA Intern Med. 2013;173:1980-90. https:// doi.org/10.1001/jamainternmed.2013.10408.

55. Miao J, Chen L, Wang J, Wang W, Chen D, Li L, et al. Current methodologies on genotyping for nosocomial pathogen methicillin-resistant Staphylococcus aureus (MRSA). Microb Pathog. 2017;107:17-28. https:// doi.org/10.1016/j.micpath.2017.03.010.

56. Kinross P, Petersen A, Skov R, Van Hauwermeiren E, Pantosti A, Laurent F, et al. Livestock-associated meticillin-resistant Staphylococcus aureus (MRSA) among human MRSA isolates, European Union/European Economic Area countries, 2013. Euro Surveill. 2017;22:16-00696. https:// doi.org/10.2807/1560-7917.ES.2017.22.44.16-00696.

57. Melles DC, Gorkink RFJ, Boelens HAM, Snijders SV, Peeters JK, Moorhouse MJ, et al. Natural population dynamics and expansion of pathogenic clones of Staphylococcus aureus. J Clin Invest. 2004;1 14:1732-40. https://doi.org/10.1172/JCI23083.

58. Van Cleef BAGL, Van Benthem BHB, Verkade EJM, Van Rijen MML, Kluytmans-van den Bergh MFQ, Graveland H, et al. Health and health-related quality of life in pig farmers carrying livestock-associated methicillinresistant Staphylococcus aureus. Epidemiol Infect. 2016;144:1774-83. https://doi.org/10.1017/S0950268815003192.

59. Wardyn SE, Forshey BM, Farina SA, Kates AE, Nair R, Quick MK, et al. Swine farming is a risk factor for infection with and high prevalence of carriage of multidrug-resistant Staphylococcus aureus. Clin Infect Dis. 2015;61:59-66. https://doi.org/10.1093/cid/civ234.

60. Mroczkowska A, Żmudzki J, Marszałek N, Orczykowska-Kotyna M, Komorowska I, Nowak A, et al. Livestock-associated Staphylococcus aureus on Polish pig farms. PLoS ONE. 2017;12: e0170745. https://doi. org/10.1371/journal.pone.0170745.

61. Wang XL, Li L, Li SM, Huang JY, Fan YP, Yao ZJ, et al. Phenotypic and molecular characteristics of Staphylococcus aureus and methicillinresistant Staphylococcus aureus in slaughterhouse pig-related workers and control workers in Guangdong Province China. Epidemiol Infect. 2017;145:1843-51. https://doi.org/10.1017/S0950268817000085.

62. Huber H, Koller S, Giezendanner N, Stephan R, Zweifel C. Prevalence and characteristics of meticillin-resistant Staphylococcus aureus in humans in contact with farm animals, in livestock, and in food of animal origin, Switzerland, 2009. Euro Surveill. 2010;15:19542. https://doi.org/10.2807/ ese.15.16.19542-en.

63. Chen C, Wu F. Livestock-associated methicillin-resistant Staphylococcus aureus (LA-MRSA) colonisation and infection among livestock workers and veterinarians: a systematic review and meta-analysis. Occup Environ Med. 2020;15:oemed-2020-106418. https://doi.org/10.1136/ oemed-2020-106418.

64. George AN, Stewart JR, Evans JC, Gibson JMD. Risk of antibiotic-resistant Staphylococcus aureus dispersion from hog farms: a critical review. Risk Anal. 2020;40:1645-65. https://doi.org/10.1111/risa.13495.

65. Chen L, Tang Z-Y, Cui S-Y, Ma Z-B, Deng H, Kong W-L, et al. Biofilm production ability, virulence and antimicrobial resistance genes in Staphylococcus aureus from various veterinary hospitals. Pathogens. 2020:9:264. https://doi.org/10.3390/pathogens9040264.

66. Schmidt JS, Kuster SP, Nigg A, Dazio V, Brilhante M, Rohrbach H, et al. Poor infection prevention and control standards are associated with environmental contamination with carbapenemase-producing Enterobacterales and other multidrug-resistant bacteria in Swiss companion animal clinics. Antimicrob Resist Infect Control. 2020;9:93. https://doi. org/10.1186/s13756-020-00742-5.

67. Kittl S, Brodard I, Heim D, Andina-Pfister P, Overesch G. Methicillinresistant Staphylococcus aureus strains in Swiss pigs and their relation to isolates from farmers and veterinarians. Appl Environ Microbiol. 2020;86:1-12. https://doi.org/10.1128/AEM.01865-19.

68. Neradova K, Jakubu V, Pomorska K, Zemlickova H. Methicillin-resistant Staphylococcus aureus in veterinary professionals in 2017 in the Czech Republic. BMC Vet Res. 2020;16:4. https://doi.org/10.1186/ s12917-019-2223-Z.

69. Taus K, Schmoll F, El-Khatib Z, Auer H, Holzmann H, Aberle S, et al. Occupational swine exposure and Hepatitis E virus, Leptospira, Ascaris suum seropositivity and MRSA colonization in Austrian 
veterinarians, 2017-2018-A cross-sectional study. Zoonoses Public Health. 2019;66:842-51. https://doi.org/10.1111/zph.12633.

70. Verkola M, Pietola E, Järvinen A, Lindqvist K, Kinnunen PM, Heikinheimo A. Low prevalence of zoonotic multidrug-resistant bacteria in veterinarians in a country with prudent use of antimicrobials in animals. Zoonoses Public Health. 2019;66:667-78. https://doi.org/10.1111/zph. 12619.

71. Tabatabaei S, Najafifar A, Askari Badouei M, Zahraei Salehi T, Ashrafi Tamai I, Khaksar E, et al. Genetic characterisation of methicillin-resistant Staphylococcus aureus and Staphylococcus pseudintermedius in pets and veterinary personnel in Iran: new insights into emerging methicillin-resistant S. pseudintermedius (MRSP). J Glob Antimicrob Resist. 2019;16:6-10. https://doi.org/10.1016/j.jgar.2018.08.022.

72. Sun J, Yang M, Sreevatsan S, Bender JB, Singer RS, Knutson TP, et al. Longitudinal study of Staphylococcus aureus colonization and infection in a cohort of swine veterinarians in the United States. BMC Infect Dis. 2017;17:690. https://doi.org/10.1186/s12879-017-2802-1.

73. Post V, Harris LG, Morgenstern M, Geoff Richards R, Sheppard SK, Moriarty TF. Characterization of nasal methicillin-resistant Staphylococcus aureus isolated from international human and veterinary surgeons. J Med Microbiol. 2017;66:360-70. https://doi.org/10.1099/jmm.0.000415.

74. Walter J, Espelage W, Cuny C, Jansen A, Witte W, Eckmanns T, et al, Veterinarians visiting swine farms are at high risk for colonization with livestock-associated methicillin-resistant Staphylococcus aureus. Clin Infect Dis. 2016;62:126-8. https://doi.org/10.1093/cid/civ752.

75. Steinman A, Masarwa S, Tirosh-Levy S, Gleser D, Kelmer G, Adler A, et al. Methicillin-resistant Staphylococcus aureus spa type t002 outbreak in horses and staff at a veterinary teaching hospital after its presumed introduction by a veterinarian. J Clin Microbiol. 2015;53:2827-31. https://doi.org/10.1128/JCM.00090-15.

76. Verkade E, Kluytmans-van den Bergh $M$, van Benthem B, van Cleef $B$ van Rijen M, Bosch T, et al. Transmission of methicillin-resistant Staphylococcus aureus CC398 from livestock veterinarians to their household members. PLoS One. 2014;9:e100823. https://doi.org/10.1371/journal. pone. 0100823 .

77. Wettstein Rosenkranz K, Rothenanger E, Brodard I, Collaud A, Overesch G, Bigler B, et al. Nasal carriage of methicillin-resistant Staphylococcus aureus (MRSA) among Swiss veterinary health care providers: detection of livestock- and healthcare-associated clones. Schweiz Arch Tierheilkd. 2014;156:317-25. https://doi.org/10.1024/0036-7281/a000601.

78. Ishihara K, Saito M, Shimokubo N, Muramatsu Y, Maetani S, Tamura Y. Methicillin-resistant Staphylococcus aureus carriage among veterinary staff and dogs in private veterinary clinics in Hokkaido. Japan Microbiol Immunol. 2014;58:149-54. https://doi.org/10.1111/1348-0421.12128.

79. Paterson GK, Harrison EM, Craven EF, Petersen A, Larsen AR, Ellington $\mathrm{MJ}$, et al. Incidence and characterisation of methicillin-resistant Staphylococcus aureus (MRSA) from nasal colonisation in participants attending a cattle veterinary conference in the UK. PLOS ONE. 2013;8: e68463. https://doi.org/10.1371/journal.pone.0068463.

80. Boost M, Ho J, Guardabassi L, O'Donoghue M. Colonization of butchers with livestock-associated methicillin-resistant Staphylococcus aureus. Zoonoses Public Health. 2013;60:572-6. https://doi.org/10.1111/zph. 12034.

81. Schwaber MJ, Navon-Venezia S, Masarwa S, Tirosh-Levy S, Adler A, Chmelnitsky l, et al. Clonal transmission of a rare methicillin-resistant Staphylococcus aureus genotype between horses and staff at a veterinary teaching hospital. Vet Microbiol. 2013;162:907-11. https://doi.org/ 10.1016/j.vetmic.2012.11.020.

82. Garcia-Graells C, Antoine J, Larsen J, Catry B, Skov R, Denis O. Livestock veterinarians at high risk of acquiring methicillin-resistant Staphylococcus aureus ST398. Epidemiol Infect. 2012;140:383-9. https://doi.org/10. 1017/S0950268811002263.

83. Paul NC, Moodley A, Ghibaudo G, Guardabassi L. Carriage of methicillinresistant Staphylococcus pseudintermedius in small animal veterinarians: indirect evidence of zoonotic transmission. Zoonoses Public Health. 2011:58:533-9. https://doi.org/10.1111/j.1863-2378.2011. 01398.x.

84. Jordan D, Simon J, Fury S, Moss S, Giffard P, Maiwald M, et al. Carriage of methicillin-resistant Staphylococcus aureus by veterinarians in Australia. Aust Vet J. 2011;89:152-9. https://doi.org/10.1111/j.1751-0813.2011. 00710.x.
85. Zhang W, Hao Z, Wang Y, Cao X, Logue CM, Wang B, et al. Molecular characterization of methicillin-resistant Staphylococcus aureus strains from pet animals and veterinary staff in China. Vet J. 2011;190:e125-9. https://doi.org/10.1016/j.tvjl.2011.02.006.

86. Horgan M, Abbott Y, Lawlor PG, Rossney A, Coffey A, Fitzgerald GF, et al. A study of the prevalence of methicillin-resistant Staphylococcus aureus in pigs and in personnel involved in the pig industry in Ireland. Vet J. 2011;190:255-9. https://doi.org/10.1016/j.tvjl.2010.10. 025.

87. Ben Slama K, Gharsa H, Klibi N, Jouini A, Lozano C, Gómez-Sanz E, et al. Nasal carriage of Staphylococcus aureus in healthy humans with different levels of contact with animals in Tunisia: genetic lineages, methicillin resistance, and virulence factors. Eur J Clin Microbiol Infect Dis. 2011:30:499-508. https://doi.org/10.1007/s10096-010-1109-6.

88. Ishihara K, Shimokubo N, Sakagami A, Ueno H, Muramatsu Y, Kadosawa $\mathrm{T}$, et al. Occurrence and molecular characteristics of methicillin-resistant Staphylococcus aureus and methicillin-resistant Staphylococcus pseudintermedius in an academic veterinary hospital. Appl Environ Microbiol. 2010;76:5165-74. https://doi.org/10.1128/AEM.02780-09.

89. Burstiner LC, Faires M, Weese JS. Methicillin-resistant Staphylococcus aureus colonization in personnel attending a veterinary surgery conference. Vet Surg. 2010;39:150-7. https://doi.org/10.1111/j.1532-950X. 2009.00638.x

90. Boost MV, So SYC, Perreten V. Low rate of methicillin-resistant coagulase-positive staphylococcal colonization of veterinary personnel in Hong Kong. Zoonoses Public Health. 2011;58:36-40. https://doi.org/ 10.1111/j.1863-2378.2009.01286.x.

91. Heller J, Armstrong SK, Girvan EK, Reid SWJ, Moodley A, Mellor DJ. Prevalence and distribution of meticillin-resistant Staphylococcus aureus within the environment and staff of a university veterinary clinic. J Small Anim Pract. 2009:50:168-73. https://doi.org/10.1111/j.17485827.2008.00695.x.

92. Zemlicková H, Fridrichová M, Tyllová K, Jakubů V, Machová I. Carriage of methicillin-resistant Staphylococcus aureus in veterinary personnel. Epidemiol Infect. 2009;137:1233-6. https://doi.org/10.1017/\$095026880 9002015.

93. Meemken D, Cuny C, Witte W, Eichler U, Staudt R, Blaha T. Occurrence of MRSA in pigs and in humans involved in pig production-preliminary results of a study in the northwest of Germany. Dtsch Tierarztl Wochenschr. 2008;115:132-9.

94. Moodley A, Nightingale EC, Stegger M, Nielsen SS, Skov RL, Guardabassi L. High risk for nasal carriage of methicillin-resistant Staphylococcus aureus among Danish veterinary practitioners. Scand J Work Environ Health. 2008;34:151-7. https://doi.org/10.5271/sjweh.1219.

95. Price LB, Stegger M, Hasman H, Aziz M, Larsen J, Andersen PS, et al. Staphylococcus aureus CC398: host adaptation and emergence of methicillin resistance in livestock. MBio. 2012;3:1-7. https://doi.org/10. 1128/mBio.00305-11.

96. Feltrin F, Alba P, Kraushaar B, lanzano A, Argudín MA, Di Matteo P, et al. A livestock-associated, multidrug-resistant, methicillin-resistant Staphylococcus aureus clonal complex 97 lineage spreading in dairy cattle and pigs in Italy. Appl Environ Microbiol. 2016;82:816-21. https://doi.org/10. 1128/AEM.02854-15.

97. Brennan Gl, Abbott Y, Burns A, Leonard F, McManus BA, O'Connell B, et al. The emergence and spread of multiple livestock-associated clonal complex 398 methicillin-resistant and methicillin-susceptible Staphylococcus aureus strains among animals and humans in the Republic of Ireland, 2010-2014. PLoS ONE. 2016;11: e0149396. https://doi.org/10. 1371/journal.pone.0149396.

98. EMA (European Medicines Agency), ESVAC (European Surveillance of Veterinary Antimicrobial Consumption). Sales of veterinary antimicrobial agents in 31 European countries in 2017. Ninth ESVAC Rep. 2019;(EMA/294674/2019).

99. EFSA (European Food Safety Authority), ECDC (European Centre for Disease Prevention and Control). The European Union summary report on antimicrobial resistance in zoonotic and indicator bacteria from humans, animals and food in 2017. EFSA J. 2019;17:e05598. https://doi. org/10.2903/j.efsa.2019.5598.

100. Collins J, Rudkin J, Recker M, Pozzi C, O'Gara JP, Massey RC. Offsetting virulence and antibiotic resistance costs by MRSA. ISME J. 2010;4:57784. https://doi.org/10.1038/ismej.2009.151. 
101. Zhang D, Cui K, Wang T, Dong H, Feng W, Ma C, et al. Trends in and correlations between antibiotic consumption and resistance of Staphylococcus aureus at a tertiary hospital in China before and after introduction of an antimicrobial stewardship programme. Epidemiol Infect. 2018;147:1-6. https://doi.org/10.1017/S095026881 8003059 .

102. Kardas-Sloma L, Boëlle P-Y, Opatowski L, Guillemot D, Temime L. Antibiotic reduction campaigns do not necessarily decrease bacterial resistance: the example of methicillin-resistant Staphylococcus aureus. Antimicrob Agents Chemother. 2013;57:4410-6. https://doi.org/10. 1128/AAC.00711-13.

103. Fuentes-Hernandez A, Plucain J, Gori F, Pena-Miller R, Reding C, Jansen $G$, et al. Using a sequential regimen to eliminate bacteria at sublethal antibiotic dosages. PLoS Biol. 2015;13:e1002104. https://doi.org/10. 1371/journal.pbio.1002104.

104. Ledda A, Price JR, Cole K, Llewelyn MJ, Kearns AM, Crook DW, et al. Reemergence of methicillin susceptibility in a resistant lineage of Staphylococcus aureus. J Antimicrob Chemother. 2017;72:1285-8. https://doi. org/10.1093/jac/dkw570.

105. Goerge T, Lorenz MB, van Alen S, Hübner N-O, Becker K, Köck R. MRSA colonization and infection among persons with occupational livestock exposure in Europe: Prevalence, preventive options and evidence. Vet Microbiol. 2017;200:6-12. https://doi.org/10.1016/j.vetmic.2015.10.027.

106. Schulz J, Boklund A, Toft N, Halasa T. Effects of control measures on the spread of LA-MRSA among Danish pig herds between 2006 and 2015 - a simulation study. Sci Rep. 2019;9:691. https://doi.org/10.1038/ s41598-018-37075-8.

107. Normanno G, Dambrosio A, Lorusso V, Samoilis G, Di Taranto P, Parisi A. Methicillin-resistant Staphylococcus aureus (MRSA) in slaughtered pigs and abattoir workers in Italy. Food Microbiol. 2015;51:51-6. https://doi. org/10.1016/j.fm.2015.04.007.

108. Courvalin P. Vancomycin resistance in gram-positive cocci. Clin Infect Dis. 2006;42:S25-34. https://doi.org/10.1086/491711.

109. Bhattacharyya D, Banerjee J, Bandyopadhyay S, Mondal B, Nanda PK, Samanta I, et al. First report on vancomycin-resistant Staphylococcus aureus in bovine and caprine milk. Microb Drug Resist. 2016;22:675-81. https://doi.org/10.1089/mdr.2015.0330.

110. Van Boeckel TP, Glennon EE, Chen D, Gilbert M, Robinson TP, Grenfell BT, et al. Reducing antimicrobial use in food animals. Science. 2017:357:1350-2. https://doi.org/10.1126/science.aao1495.

111. Charlier C, Cretenet M, Even S, Le Loir Y. Interactions between Staphylococcus aureus and lactic acid bacteria: an old story with new perspectives. Int J Food Microbiol. 2009;131:30-9. https://doi.org/10.1016/j.ijfoo dmicro.2008.06.032

112. Ocaña VS, Pesce de Ruiz Holgado AA, Nader-Macías ME. Selection of vaginal $\mathrm{H} 2 \mathrm{O} 2$-generating Lactobacillus species for probiotic use. Curr Microbiol. 1999;38:279-84. https://doi.org/10.1007/pl00006802.

113. Ocaña VS, de Ruiz Holgado AA, Nader-Macías ME. Growth inhibition of Staphylococcus aureus by $\mathrm{H} 2 \mathrm{O} 2$-producing Lactobacillus paracasei subsp. paracasei isolated from the human vagina. FEMS Immunol Med Microbiol. 1999;23:87-92. https://doi.org/10.1111/j.1574-695X.1999. tb01227.x.

114. Tachedjian G, O'Hanlon DE, Ravel J. The implausible "in vivo" role of hydrogen peroxide as an antimicrobial factor produced by vaginal microbiota. Microbiome. 2018;6:29. https://doi.org/10.1186/ s40168-018-0418-3.

115. Gan BS, Kim J, Reid G, Cadieux P, Howard JC. Lactobacillus fermentum RC-14 inhibits Staphylococcus aureus infection of surgical implants in rats. J Infect Dis. 2002;185:1369-72. https://doi.org/10.1086/340126.

116. Warrack S, Panjikar P, Duster M, Safdar N. Tolerability of a probiotic in subjects with a history of methicillin-resistant Staphylococcus aureus colonisation. Benef Microbes. 2014;5:389-95. https://doi.org/10.3920/ BM2013.0062.

117. Glück U, Gebbers J-O. Ingested probiotics reduce nasal colonization with pathogenic bacteria (Staphylococcus aureus, Streptococcus pneumoniae, and beta-hemolytic streptococci). Am J Clin Nutr. 2003;77:51720. https://doi.org/10.1093/ajcn/77.2.517.

118. Roos K, Simark-Mattsson C, Grahn Håkansson E, Larsson L, Sandberg T, Ahrén C. Can probiotic lactobacilli eradicate persistent carriage of meticillin-resistant Staphylococcus aureus? J Hosp Infect. 2011;78:77-8. https://doi.org/10.1016/j.jhin.2011.01.010.
119. Guo X, Li D, Lu W, Piao X, Chen X. Screening of Bacillus strains as potential probiotics and subsequent confirmation of the in vivo effectiveness of Bacillus subtilis MA139 in pigs. Antonie Van Leeuwenhoek. 2006;90:139-46. https://doi.org/10.1007/ s10482-006-9067-9.

120. Piewngam P, Zheng Y, Nguyen TH, Dickey SW, Joo H-S, Villaruz AE, et al. Pathogen elimination by probiotic Bacillus via signalling interference. Nature. 2018;562:532-7. https://doi.org/10.1038/s41586-018-0616-y.

121. Le KY, Otto M. Quorum-sensing regulation in staphylococci-an overview. Front Microbiol. 2015;6:1174. https://doi.org/10.3389/fmicb.2015. 01174.

122. Terra L, Dyson PJ, Hitchings MD, Thomas L, Abdelhameed A, Banat IM, et al. A novel alkaliphilic Streptomyces inhibits ESKAPE pathogens. Front Microbiol. 2018;9:2458. https://doi.org/10.3389/fmicb.2018.02458.

123. Verstappen KM, Willems E, Fluit AC, Duim B, Martens M, Wagenaar JA. Staphylococcus aureus nasal colonization differs among pig lineages and is associated with the presence of other staphylococcal species. Front Vet Sci. 2017:4:97. https://doi.org/10.3389/fvets.2017.00097.

124. Bruynoghe R, Maisin J. Essais de thérapeutique au moyen du bacteriophage. C R Seances Soc Biol Fil. 1921;85:1120-1.

125. Lu TK, Koeris MS. The next generation of bacteriophage therapy. Curr Opin Microbiol. 2011;14:524-31. https://doi.org/10.1016/j.mib.2011.07. 028.

126. Fenton M, Casey PG, Hill C, Gahan CGM, Ross RP, McAuliffe O, et al. The truncated phage lysin CHAP(k) eliminates Staphylococcus aureus in the nares of mice. Bioeng Bugs. 2010;1:404-7. https://doi.org/10.4161/ bbug.1.6.13422.

127. Matsuzaki S, Yasuda M, Nishikawa H, Kuroda M, Ujihara T, Shuin T, et al. Experimental protection of mice against lethal Staphylococcus aureus infection by novel bacteriophage phi MR11.J Infect Dis. 2003;187:61324. https://doi.org/10.1086/374001.

128. Haddad Kashani H, Schmelcher M, Sabzalipoor H, Seyed Hosseini E, Moniri R. Recombinant endolysins as potential therapeutics against antibiotic-resistant Staphylococcus aureus: Current status of research and novel delivery strategies. Clin Microbiol Rev. 2018;31:e00071-e117. https://doi.org/10.1128/CMR.00071-17.

129. Vos MC, Behrendt MD, Melles DC, Mollema FPN, de Groot W, Parlevliet $\mathrm{G}$, et al. 5 years of experience implementing a methicillin-resistant Staphylococcus aureus search and destroy policy at the largest university medical center in the Netherlands. Infect Control Hosp Epidemiol. 2009;30:977-84. https://doi.org/10.1086/605921.

130. Wertheim HFL, Vos MC, Boelens HAM, Voss A, Vandenbroucke-Grauls CMJE, Meester MHM, et al. Low prevalence of methicillin-resistant Staphylococcus aureus (MRSA) at hospital admission in the Netherlands: the value of search and destroy and restrictive antibiotic use. J Hosp Infect. 2004:56:321-5. https://doi.org/10.1016/j.jhin.2004.01.026.

131. Huang SS, Septimus E, Kleinman K, Moody J, Hickok J, Avery TR, et al. Targeted versus universal decolonization to prevent ICU infection. N Engl J Med. 2013;368:2255-65. https://doi.org/10.1056/NEJMoa1207290.

132. Kourtis AP, Hatfield K, Baggs J, Mu Y, See I, Epson E, et al. Vital signs: Epidemiology and recent trends in methicillin-resistant and in methicillinsusceptible Staphylococcus aureus bloodstream infections - United States. MMWR Morb Mortal Wkly Rep. 2019;68:214-9. https://doi.org/ 10.15585/mmwr.mm6809e1.

133. Gibbons JF, Markey BK, Jahns H, Boland F, Abbott Y, Burns A, et al. Investigation of the persistence and transmission of MRSA CC 5 in pigs following intra-nasal inoculation. Vet Microbiol. 2013;162:771-8. https:// doi.org/10.1016/j.vetmic.2012.10.001.

134. Angen $\varnothing$, Feld L, Larsen J, Rostgaard K, Skov R, Madsen AM, et al. Transmission of methicillin-resistant Staphylococcus aureus to human volunteers visiting a swine farm. Appl Environ Microbiol. 2017;83:1-10. https://doi.org/10.1128/AEM.01489-17.

135. Angen $\varnothing$, Skade L, Urth TR, Andersson M, Bækbo P, Larsen AR. Controlling transmission of MRSA to humans during short-term visits to swine farms using dust masks. Front Microbiol. 2019;9:3361. https://doi.org/ 10.3389/fmicb.2018.03361.

\section{Publisher's Note}

Springer Nature remains neutral with regard to jurisdictional claims in published maps and institutional affiliations. 